\title{
Civilisations
}

Revue internationale d'anthropologie et de sciences

humaines

$57 \mid 2008$

Tourisme, mobilités et altérités contemporaines

\section{Diasporic visitor, diasporic tourist}

Post-migrant generation Moroccans on holiday at 'home' in Morocco

Lauren Wagner

\section{(2) OpenEdition}

Journals

Édition électronique

URL : http://journals.openedition.org/civilisations/1396

DOI : 10.4000/civilisations. 1396

ISSN : 2032-0442

Éditeur

Institut de sociologie de l'Université Libre de Bruxelles

Édition imprimée

Date de publication : 29 décembre 2008

Pagination : 191-205

ISBN : 2-87263-022-8

ISSN : 0009-8140

Référence électronique

Lauren Wagner, "Diasporic visitor, diasporic tourist », Civilisations [En ligne], 57 | 2008, mis en ligne le 29 décembre 2011, consulté le 02 mai 2019. URL : http://journals.openedition.org/civilisations/1396 ; DOI : 10.4000/civilisations. 1396

(c) Tous droits réservés 


\title{
Diasporic visitor, diasporic tourist \\ Post-migrant generation Moroccans on holiday at 'bome' in Morocco
}

\author{
Lauren WAGNER
}

Résumé : Les membres de diasporas qui se rendent en visite dans leur pays d'origine éprouvent souvent le sentiment paradoxal d'être "touristes dans leur propre pays ». Cet article explore ce paradoxe à travers la présentation de données ethnographiques concernant des Européens d'origine marocaine de la génération poste-migrante qui passent leurs vacances d'été au Maroc. Ces personnes rendent compte de leur visite comme d'un "retour chez eux », mais leurs comportements et leurs choix de loisirs montrent souvent que leurs visites sont plus, et autre chose, que de simples visites familiales. Cela permet de montrer que ces visiteurs se comportent et se considèrent à la fois comme des locaux et comme des touristes, la façon dont ces deux identités s'imbriquent variant selon les cas.

Mots-clés : diaspora, tourisme, appartenance, migration, Maroc.

Abstract: Diasporic populations who visit the 'homeland' often describe a paradoxical sense of being a 'tourist in their own home'. This article explores this dynamic through ethnographic data on post-migrant generation Moroccans from Europe who spend their summer holidays in Morocco. Although these individuals characterise their visits as 'going home', how they choose to spend their time on vacation indicates that the holiday is more than simply a visit to the family home, calling into question how the diasporic community relates to their place of origin as both 'locals' and 'tourists'.

Key words: diaspora, tourism, belonging, migration, Morocco. 
$\mathrm{T}$ he concept of tourism would seem necessarily antithetical to the concept of diaspora: the one implies cursory and superficial connections with a place away from the place of residence, whereas the other implies rooted and profound ones. Tourists are those who do not 'know' the place intimately, who consume it through representations (Kirshenblatt-Gimblett 1998; Rojek and Urry 1997) and, because of the temporary nature of their stay, are unable to appreciate the density of the space they visit. Diaspora members, although they may have relatively little experience being there, often have an instilled sense of cultural awareness inextricably linked to the space of 'home', learned by the ways they and their families practice belonging to their particular diasporic community. The tension between these two positions, that of the unknowing tourist and the intimately knowledgeable diaspora member, provides the foundation for this investigation into the modes of consumption and of interaction enacted by Moroccan post-migrant generation diasporic visitors when they choose to 'return home' to Morocco on holiday.

In order to address this configuration as it is specific to Morocco, to migrant communities from Morocco, and to the holidays post-migrant generation members of these communities spend in Morocco, this paper presents first a theoretical intersection between 'diaspora' and 'tourism' through the dynamic of 'home'. The data presented, gathered from experiences of Moroccan post-migrant generation visitors during visits to Morocco, reflects on how 'home' might be interpreted both as the experience of family connection in a place of origin and as the touristic consumption of Morocco as a 'homeland'.

\section{From diaspora to diasporic}

From its original restricted application to certain historically specific cases of population dispersal (Gilroy 1993; Tölöyan 1996; Schnapper 1999; Shuval 2000), diaspora has been used in reference to various large-scale movements (Cohen 1997) and to different approaches to attachment to a distant homeland (Anthias 1998; Werbner 2002; Mavroudi 2007). Cohen in particular is concerned with defining 'diaspora' as representing only migrant groups that adhere to certain qualities of their exodus and composition (1997: 180), which would include the Moroccan 'diaspora'. However, the application of a broad term to all those who migrated from Morocco, regardless of their conditions of migration, may engender imaginings of a level of unity and solidarity among different Moroccan migrant communities that cannot be demonstrated. In lieu of applying 'diaspora' in general, I suggest describing some of their practices as 'diasporic'.

\section{Diasporic attachment}

'Diasporic' in the adjectival sense, as opposed to the mass of 'diaspora', is used here to describe a connection to an (imagined) homeland, and a sense of belonging in the (imagined) cultural/social space of that homeland. Diasporic individuals may have political or economic (transnational) projects that involve the homeland, but they are projects generally situated in and perpetrated from an external space. These projects may use the homeland as a source of reference, or a reason for action, but they are projects 
that impact primarily lives and activities elsewhere ${ }^{1}$. Diasporic could be equally applied to movement from region to region within one nation as to movement from nation to nation.

Additionally, 'diasporic' refers to distance through space in Massey's sense (2005) that is both spatial and temporal. That is, diasporic pull can reflect nostalgic impulses for moments of past experiences alongside involvement in dynamics of distant places. Naming these individuals as 'diasporic,' instead of some other common terms like hybrid or transnational, recognises that the source of influence on their identities is situated in a specific distant space - a 'home' - to which they are connected to through 'rootedness' of familial origin.

In this sense, discussions about diasporic visits to the country of parental origin, in this case Morocco, are often characterized by discourses of 'home' or 'return', whether or not the individual in fact resided in Morocco. Yet the European community is equally thought of as a 'home', at times more so in the sense of being a place of residence and of the year-round activity of 'normal' life. It is the diasporic nature of the connection that allows the metaphor of 'home' to be acceptable to describe a distant place: as Brah (1996) describes it, diaspora "offers a critique of discourses of fixed origin, while taking account of a homing desire which is not the same thing as desire for a "homeland" (1996:180).

Her description emphasises the displacedness of the diasporic without pairing it to a de-culturation or de-nationalisation. It recontextualises the paired concepts of 'home' and 'location', neither of which are fixed in space in a diasporic sense. Instead, these elements alternate between conjunction and disjunction: both the diasporic centre and the place of residence are equally definable as home, and are equally places of location and dislocation for diasporic individuals:

"Where is home? On the one hand, 'home' is a mythic place of desire in the diasporic imagination. In this sense it is a place of no return, even if it is possible to visit the geographical territory that is seen as the place of 'origin'. On the other hand, home is also the lived experience of a locality. Its sounds and smells, its heat and dust, balmy summer evenings, or the excitement of the first snowfall, shivering winter evenings, somber grey skies in the middle of the day... all this, as mediated by the historically specific everyday of social relations" (Brah 1996: 192)

She continues: "The question of home, therefore, is intrinsically linked with the way in which processes of inclusion or exclusion operate and are subjectively experienced under given circumstances. It is centrally about our political and personal struggles over the social regulation of "belonging"" (ibid.). Or, as Ahmed expresses it, "the question of home and being-at-home can only be addressed by considering the question of affect: being-at-home is a matter of how one feels or how one might fail to feel" (2000: 89).

1. More specifically, they are not engaged in transnational projects as Portes and Rumbaut (2001) seek to define them, as simultaneously and intensively building their lives in two separate national spaces. On the contrary, most of the participants with whom I spoke were decidedly building their lives in their European homes, and did not intend to invest in Morocco, neither politically nor economically. 


\section{Diasporic strangeness}

Ahmed's double-sided nature of 'home' encapsulates the problematic of diasporic 'return'. As much as diasporic attachment implies closeness and connection to a diasporic centre, it also implies a necessary distance. Dispersal from any locality leaves behind spaces that continue on their own trajectories, unimpeded by and unconscious of the distant trajectories of other linked spaces (Massey 2005: 123-125). Bringing members of the diasporic community to the diasporic centre creates an intersection of related but distinct spaces, and forces the recognition of difference, or strangeness, along with sameness.

Participants in the present study attest their awareness of what is here called diasporic strangeness in their relations with other Moroccans during the holiday. They acknowledge that they themselves are recognized as 'strange', in the sense of non-local or foreign, often relating that they are not 'accepted' in Europe, but nor are they 'accepted' in Morocco. The nature of this non-acceptance is vague, but one example is in the shopping they carry out in Morocco: post-migrant generation Moroccans complain that they are quoted higher prices than locals, being immediately recognized simply by their bodies and movement as being from 'outside'.

Thus, diasporic is not only used in reference to deep, rooted connection; the fact of making a diaspora, of moving away from the place of origin to create a community, necessitates a measure of strangeness along with familiarity. As Ahmed describes, "the experience of leaving home in migration is hence always about the failure of memory to make sense of the place one comes to inhabit, a failure that is experienced in the discomfort of inhabiting a migrant body, a body that feels out of place" (2000: 91). Much research describes this sense of a migrant body 'out of place' from the perspective of the European home (Crul and Vermeulen 2003; Gaudier and Hermans 1991; LacosteDujardin 1992; Lepoutre 1997; Taïeb 1998; Tribalat 1995). In leaving a European home to inhabit Morocco during the summer, the migrant bodies of diasporic visitors continue to be in some measure 'out of place'. It is this strangeness that connects diasporic visitors with a touristic perspective, in that visiting the 'homeland', however connected to it they might be, always involves a displacement.

\section{Diasporic tourism}

Tourism and 'the tourist' have been constructed along different lines of central logic, but with a uniting thread: that by bringing individuals into closer proximity, the act of travelling in order to experience another place generates a social distance between the travellers and the 'locals'. This distanciation has been analysed as a configuration of authenticity (MacCannell 1973), as an enactment of gaze (Urry 1990; Crang 1997) reflecting modern separations between work and leisure, and as the performance of host and guest relations on a grander scale of consumption (Smith 1977). Whereas potential tourists enact gazes and perceptions of Others amongst themselves in their own homes, in proximity their perspectives become actualised and operationalised. Tourists expect to find spaces that reflect the images and representations that drew them to visit a place, both in physical demeanour and in their exchanges with 'locals'; 'locals' expect various kinds of tourists to follow scripted performances (Coleman and Crang 2002) that mark them as strangers and constitute their experience of the place. To be a 'tourist' requires a 
certain amount of detachment from the destination; to 'consume' a place implies a lack of intimate knowledge of it.

Within tourism studies, the roles of 'hosts' or the local community has become increasingly recognised to not be a passive one. Where once tourism was seen as a force that participates in 'freezing' cultural identities into packageable entities (Ateljevic and Doorne 2003; Shepherd 2002; Meethan 2001) and training tourism workers to produce their interactions for the consuming public (Hochschild 1983), more recent approaches recognise the participation of locals in the process of producing culture for tourists, and the ways in which that process becomes a kind of cultural development in itself. "Scrupulous studies have suggested that while tourism does very often produce undesirable effects, it is not enough to see that 'cultural changes arising from tourism are produced by the intrusion of a superior sociocultural system in a supposedly weaker receiving milieu' (Picard, 1996:108). Touristic culture is more than the physical travel, it is the preparation of people to see other places as objects of tourism, and the preparation of those people and places to be seen" (Franklin and Crang 2001: 10).

This phenomenon is particularly apparent in a place like Morocco, where tourism practices adhere to models of 'third world' or 'ethnic' tourism (Van den Berghe 1994; Berriane 1999). There and in similar locations, tourist visitors are most often from higher income countries, and their expectations of the place include a certain amount of exoticism and Otherness (Minca and Oakes 2006) mixed with leisure consumption (Crouch 1999) at a lower price than can be found at home. This characterisation, at least in the case of Morocco, is not random: the first French Protectorate governor, Lyautey, reputedly began development of Marrakech (and other cities) in the early 20th century as exotic luxury leisure resorts for French visitors (Stafford and Bélanger 1996: 33). It has been reinforced by literary and artistic images that perpetuate Orientalist ideologies about Morocco (Bertolucci 1990; Bowles 1949). Such images often encourage tourists to collect experiences of a place that are stereotypical, seen to be essential stock of cultural capital gathered to prove that one has correctly 'done' the place. Diasporic visitors are not immune to these images, nor to the pursuit of collecting experiences of the place. Yet their innate relationship with the place is not the same detached stance as the archetypal tourist, which gives the acts of 'collecting' and consuming a different timbre.

\section{VFR consumption}

Studies in Visiting Friends and Relatives (VFR) tourism, often in the context of links between migration and tourism, explore the practices and impacts of those who are grouped outside of the classic 'tourist' who undertake the voyage in the context of visiting a familiar person or persons as well as the place (Hall and Williams 2002; Coles and Timothy 2004; Hollinshead 2004). Often, the focus of recent research in this genre is on how to characterize the motivations of VFR tourists (Feng and Page 2000), or on the migrant generation themselves, and the complexities of undertaking a temporary return in which material and emotional relationships with members of the home community have changed as a result of migration (Duval 2003; Asiedu 2005). Although these studies inform the current research, it is safe to infer that post-migrant generations have a much different experience of visiting 'home' than that of their parents, having little experience in that place as a place of residence. 
The work that has the most potential for comparison to the present research is that of Ali and Holden (2006), who investigated 'first' and 'second' generation British Pakistanis' discourse and practices about visiting Pakistan. Their research is framed by the 'myth of return' of migrant communities, along with the sense of nostalgia that the migrant generation generally feels for 'home' and attempts to pass on to future generations by giving them an experience of the place through visiting.

Through interviews with numerous families based in Luton, UK, Ali and Holden (2006) investigate primarily tropes of being and belonging in the Pakistani community linked with the 'return' trip. Their line of questioning reflects a dichotomy of 'being' Pakistani or 'being' British, including questions like 'Where is home?' and 'What are you?' They frame the 'return' trip as a primary socialisation device (2006: 222), something learned in the home that would then likely be repeated in adulthood. In their conclusions, however, Ali and Holden find that the 'second' generation perform the holiday out of a sense of duty to their parents (2006: 237), while parents "agonise over a loss of the Pakistani-ness within them" (2006: 239).

Some contend that these visits are a means of cementing family links and increasing social capital with reference to family (Duval 2004a; Duval 2004b; Nguyen and King 2004). Family interactions can be a focal point of the visit, but many of the activities engaged in are not exclusively family-oriented (Feng and Page 2000). Research shows that visiting migrants are also consumers, and in particular ways that may differ from other tourists, but adhere to a touristic logic of consumption of leisure spaces, cultural spaces and other non-essential purchases (Duval 2003). The post-migrant generation's consumption habits while on holiday at 'home' are still a mystery, as none of the available research is concerned with first-hand experiences of the 'second' generation.

Prior research framed by the dynamic of VFR tourism would therefore suggest that these visits home integrate a desire for connection to the diasporic centre by enacting 'being' part of that community through reviving relationships with family members. There are indications as well that VFR tourists are also 'tourists', in that they are interested in visiting and experiencing some of the more typical kinds of touristic consumption spaces available in the community. The post-migrant generations, however, are not expected to be motivated necessarily by their own desire to reconnect with family or with an ethnic identity, instead performing these visits out of a sense of familial obligation.

\section{Constituting a Moroccan diasporic visitor}

The analyses presented here are based on an ethnography of the space (Massey 2005) of a summer holiday, in which the visitors and the visited are from the same ethnic origin but different social, linguistic and economic backgrounds stretched across diasporic space. Specifically, it concerns Dutch, Belgian and French persons from families where both parents migrated from Morocco during the 'guestworker' labour migration period (1963-1974) and during the subsequent family reunion period, and who themselves were born in Europe or migrated before beginning school at age four, and who are now adults. The size of the total population is difficult to estimate, given conflicting state-based methods of attribution of national identity in census data, but is in the range of 800000 to 1,5 million people ${ }^{2}$.

Approximately 130 individuals contributed to this study at different levels of participation. Most participants were found randomly by approaching individuals on the 
street in Morocco during summer holiday periods with a survey questionnaire. Those who indicated further willingness to participate were contacted to be interviewees or permitted me to join them during their holidays as a participant observer. Periods of participant observation ranged from an hour spent shopping to a week in the family home or sharing a hotel room. Other participants were incorporated through personal contacts and snowball sampling within an extended family.

Data for this ethnography comes from a number of sources, both within Morocco and within Europe. Following Katz's (1999) analyses of emotion in context and other work in ethnomethdology (Garfinkel 1984, Clayman and Maynard 1994) and conversation analysis (Sacks 1998), situation and context are considered of primary importance in analysing moments of data collection. Narratives of experience on the holiday, for example, are not isolated from the context or events which prompted their recitation, whether at 'home' in Europe in a traditional semi-structured interview setting or at 'home' in Morocco in an 'ethnographic interview' setting. As Katz describes it, priority is given to 'naturally occurring' data, which is observed ethnographically in its 'natural' setting by the researcher, because "[w]hen people generalize about what they do, much less try to explain why they do it, what they say is extremely suspect as anything other than an artifact of the inquiry" (1999: 8, italics original). In the present analysis, priority is given to situations that play out during the holidays as representing the dynamic of diasporic connection as it exists there, and descriptions made at a distance (in Europe) as representing a different aspect of this dynamic, a discourse that occurs in displacement.

In this respect, Katz likewise encourages "tak[ing] subjects' metaphors seriously" (1999: 10), because "At the most fundamental level of emotional experience and conduct, there is no nonmetaphoric, nonfigurative, 'literal' level of reality to address" (ibid). Thus, 'home' and 'tourist', as metaphors for ways that post-migrant generation Moroccans from Europe imagine and enact being in Morocco are here presented as two inseparable sides of the same dynamic. Two cases will be described: the first an example of 'home' as it is typically imagined as a visit primarily motivated by seeing family; the second and example of a 'tourist' diasporic visitor, whose primary motivations are not at all linked to the family 'home'.

\section{Being 'at home': Al Hoceima}

If there is a 'typical' imagining of a Moroccan family 'return' holiday, then Fatima's 's family embodies it: they travel every year that they can afford it, in a

2. This margin is necessarily large because of systems of categorisation at state levels across different states and different state institutions. For example, the Moroccan government classes all those in possession of Moroccan nationality as Moroccan nationals residing abroad, making no distinction between those who were born outside of Morocco and those who migrated. Even with that consideration, Moroccan nationals may not be counted as such when they cross the border if they choose to pass with a passport from another country and without presenting their national identity card. In Europe, because of the succession of changing regulations regarding the acquisition of nationality, some individuals of Moroccan origin born there are unable to acquire nationality in their country of birth. Because of this compounding of different reporting methods, it is impossible to make a fine distinction between the post-migrant generation and their parents within figures from any of the government institutions involved.

3. All names of participants are pseudonyms. 
minibus packed to the brim with presents and supplies to drive the 2-3 days from their home in the Netherlands, through Belgium, France and finally Spain (where they have never stopped to visit) to the ferry port at Almeria. In the past the wait for a ferry could add another day to the journey, but now things are much more organized and most pass within a few hours. Then the road trip starts anew, to finish the distance between their port of entry along the northern coast to their final destination, the house their father built in Al Hoceima. The house is large enough to accommodate three families, one on each floor; as her father imagined when building it, his own at the top, plus his two sons and their wives and children on the two lower floors.

Once arrived, the women have to clean the house, which has usually been left unoccupied (maybe checked on occasionally by an uncle or friend) for the last eleven months. They settle in, unpacking their food and supplies from the road, reorganising the furniture that was stacked up in storage last summer, announcing to family and friends that they have arrived. From that point on, older children, especially the boys, have freedom to roam their second hometown to meet up with their friends, many of whom make the same journey from the Netherlands to Al Hoceima or a nearby village. The younger children and girls usually stay closer to home, going out with their parents to visit other family, taking care of younger children.

They rarely travel outside of $\mathrm{Al}$ Hoceima, unless the purpose is to visit another family member outside the city; they have an uncle in Laarache and an aunt in Fes, but they don't spend time sightseeing in these towns, their parents prefer to stay in the family home. The majority of their travel outside Al Hoceima is to their grandfather's house in the village nearby, but they don't usually sleep there.

It is clear that post-migrant generation diasporic members who go 'home' on holiday do participate in family dynamics and the reinforcement of social capital within the family. Most individuals claimed that 'seeing family' is an important reason to visit Morocco, among other reasons like the opportunity to relax and feel 'at home'. Most participants however did not express a sense of obligation in the same vein that Ali and Holden (2006) found with their interviewees, but this may be linked with the fact that many participants have large extended families that migrated together, meaning that the family remaining to visit in Morocco is more distant. In fact, some participants reported spending time almost exclusively with family members who were also diasporic visitors - effectively relocating their space of interaction from the European home to the Moroccan home.

Families whose relatives continue to live in relatively inaccessible places may choose to build their 'holiday' homes in the nearby city (as is the case with the family described above) in order to take advantage of the available entertainment and increased mobility, spending only a limited time visiting the village. In fact, even when describing a visit 'home' to a place that is linked with the family, the central activities are often 'leisure' activities and not necessarily motivated by building social capital within the family. This is highlighted by a further examination of Fatima's family in Al Hoceima.

Al Hoceima has a very specific routine during the summer: everyone is at the beach during the day, one of the 27 beaches easily reachable by car, and promenading the city streets at night, crowded around Place Mohammed V, which they call 
'parki'. From 10 am, men and women meander towards the Playa, the beach in Al Hoceima proper, men wearing swim suits and t-shirts and women in 'marrakshia' (or 'bdaya), brightly colored and loosely covering dresses that are worn as pyjamas and indoor clothing elsewhere in Morocco. Fatima's cousin Karima tells me that Playa is more of a masculine beach, she prefers Sfiha, which is more of a family beach, meaning there are more women with children. Her brother Saïd says he doesn't often go to Playa, because it's a beach where people are posturing, trying to be seen. Spending a day at Playa confirms both of their opinions: I see women walking by in the barest bikinis and sense the male majority in the gazes. The men at the rental counter for jetskis and other equipment estimate about $60 \%$ of the beach-goers are Moroccans from outside, mostly Belgium and the Netherlands; the man at the snack stall thinks $40 \%$ are from elsewhere.

Standing on the main road, Boulevard Mohammed V, in the evening, watching the traffic moving slower than molasses down the hill, it's easy to count license plates; around 3/4 of them are from outside Morocco, including the Netherlands, Belgium, France, Spain, and a few from Germany. Yet looking out over the crowd in the 'parki' (pronounced by Fatima with a long Dutch 'r'), one would not necessarily spot who is European and who is not. Men are gathered in packs, watching all the women, both those dressed modestly in hijab and those wearing tanktops and daringly short skirts. Neither of these styles necessarily means 'from Morocco' or 'from Europe' but some of the more austere, dressed entirely in black or covered by a more complete, Saudi-style hijab, I am told are probably from northern Netherlands. Fatima says people only go there to pick up someone or to be picked up (male and female roles, respectively), so we don't spend much time there despite the live music stage set up and the milling crowd.

Instead, we go to Espace Miramar, a newly renovated cafe that Fatima's father and uncles frequent so much they call it amongst themselves after her father's last name. Since last summer, the cafe has expanded into a restaurant and grill, with four separate terraced seating spaces and a space for children in addition to the small main building. This expansion has broader significance than the creation of a new consumption space, as it is the only centrally-located cafe where women are also customers. Like other spaces in Hoceima it seems that at least half, if not more of the customers are visitors. Fatima is a little uncertain on our first venture there, since she may see her father and have to explain her presence in a cafe. When we return home to Sidi Abid, a neighborhood consisting primarily of houses built by migrants, she reports having been there to her mother, who is shocked both that there are women there and that Fatima herself went.

Fatima and her siblings and cousins embody a typical family visiting Al Hoceima, based on observations and conversations with others there. They spend their days at the beach or wandering the market, eating lunch with family or friends, occasionally visiting their relatives, but mostly maintaining their holiday routine. Their consumption habits of leisure spaces mark them as both 'at home' and 'tourist': although they are speaking the local dialect, visiting local family members and populating local spaces of consumption, the way they embody these activities is markedly different. Some female diasporic visitors populate cafes which are traditionally a masculine territory. Some female diasporic visitors are seen on the beach wearing bikinis to tan. Tanning in particular is an important 
example: generally, the whitest possible skin is desirable in Morocco to the point that women use harmful skin creams to bleach their skin. On the contrary, Moroccan diasporic visitors almost universally seek a deep suntan to prove their summer spent relaxing on a beach. This is a seemingly small distinction, but it reflects the broad distinctions in consumption habits that mark diasporic visitors as 'tourists'.

Not all post-migrant generation diasporic members choose to continue visiting Morocco into adulthood along with the family. Often this choice is linked to other lifechoices, like marrying a non-Moroccan spouse, or the impediment that children add to the prospect of travel over long distances. For the many that still do, it seems that Brah's notion of the diasporic 'homing desire', to return to the sensory familiarity of a 'home', influences their decision; they say they need to have their time in Morocco every year, it's a necessary part of their lives. Yet, the sense of 'home' they require is not necessarily linked to a sense of familial attachment or obligation.

On his questionnaire, in response to the question, "Do you want to bring your children back to visit Morocco?", Saïd chose yes. His reply confuses me: from the week I've spent in his family home, mostly with his sister, he doesn't seem to spend much time in the actual house. It's normal that he disappears around $11 \mathrm{am}$, only to be found again the next morning asleep in his room. He eats no meals at home, even eating out for breakfast every day for the week I am there, while his sisters and I are regularly at home for lunch. I get the sense that he spends almost every day at one of the beaches, hanging out with friends and cousins who have independent transportation.

I ask him, in the five minutes he is willing to sit for an interview, what he imagines the visits with his children would be like. He replies that he wants to show them his experience of Morocco, adding that Hoceima is getting better and better, and it's important for his (eventual) children to know where they come from.

Inferring from Saïd's answer and his habits while there, his impression of Al Hoceima as 'getting better and better' seems to be necessarily linked to the openness and diversity of things to do in the city. Saïd went on his first independent road trip with some of his cousins shortly after this conversation occurred, in the direction of Nador. His cousin Karima joined students from her university on a group holiday in Marrakech the following summer. Although they continue to visit 'home', their conceptualisation of the diasporic centre of Morocco changes with each expansion of their visits there, from the family house to other spaces within the territory of Morocco.

\section{Being a 'tourist': Marrakech}

We are sitting on the upper floor of a cafe in Marrakech. The view down the street is the Koutoubia minaret; from this height it is the most visible thing. The awnings that block the sun also seem to trap the heat, making it feel stuffy at head-level and cool on the ground. We came up for a coffee around 12:30 pm after meeting Samira's cousin Abdelhafid in front of the mosque. Samira and her American friend Julie drink mint tea, Abdelhafid and I have coffee.

There is no common language for all four of us, so Samira is mostly conversing with her cousin, who she hasn't seen for some time, in Moroccan Arabic. He is 
passing through Marrakech on his way back to her parent's home, a small town in the Sahara where I first met her sister a year previously. Samira was there as well last year, but has not been since; she has been back to Morocco twice since last summer, both times to Marrakech with friends.

At one point Abdelhafid asks: "Tell me, what is it that you like so much about Marrakech?"

Samira pauses, then replies: "The sun. And the souk, the things they have here".

Abdelhafid questions again: "But we have those things in (our town), what's the difference between there and Marrakech?"

I interject: "The airport".

Samira continues: "If I only have one week of vacation, I prefer to come here. I can relax. If I go to (our town) I have to travel for 2 days and the time is too short".

Samira gave me approximately the same reasons for not visiting her parental home in Morocco when I asked her a similar question a few days previously. Understandably so: the quickest way to arrive to her town is by an overnight, 12-hour bus ride that traverses some of the highest mountains in Morocco. On this particular trip, she invited two colleagues from work to accompany her in Marrakech, where she spent 10 days dividing her time between shopping, sunbathing, beautifying, visiting cultural sites, taking daytrips to Essaouira and the mountains, dining in a few unknown restaurants and spending a night out for her birthday. She also saw her sister and her husband, and their six year old daughter, who come so often to the same package tour hotel that the staff gave them a plate of cookies and a basket of fruit this time as a welcome present.

Yet her cousin's question is a valid one: why not spend 8 of her 10 days on holiday seeing her family in the hard-to-reach desert place rather than spending them in Marrakech with colleagues, friends, and a sister she sees much more often in France?

Whereas their parents may not voyage to other places in Morocco outside of the region to which they 'return', some post-migrant generation diasporic visitors report extensive travels within Morocco, often citing a pressure to 'know their own country' as much as other European tourists know it. These travels, like those of Samira and her sister, sometimes consist of plane voyages to cities far distant from their families in Morocco to spend a week enjoying themselves without any familial contact. In some sense, these visits are also an enactment of being 'at home' in Morocco, despite the lack of familial contact. Other places in Morocco outside the family home retain the feeling of being in a familiar place, but with increased opportunities for touristic forms of leisure consumption.

Most often the city of choice is Marrakech; notably, almost $80 \%$ of survey questionnaire respondants listed Marrakech either as a city they have visited or one they would like to visit. As the most touristed city in Morocco, it is not surprising that diasporic visitors, who are subject to the same advertising and orientalist imagery as their non-diasporic community members in Europe, would also want to experience a city that is quintessentially identified with Morocco.

What is more striking is that some, like Samira and her sister, make repeated trips to Marrakech, either alongside their visits to family homes or in lieu of such visits. Two different couples encountered during the data collection took their week long holiday in Marrakech without visiting family members who were less than 3 hours distant by car, stating their desire to relax and rest without family. They plan separate trips to family 
homes, saving some of their vacation days for the end of Ramadan. One MoroccanAlgerian couple from France chose Marrakech for their week of holiday because they found the deal on a last-minute travel website.

Many of those who are Marrakech regulars cite similar reasons for their attraction as non-diasporic tourists. Like Samira, they seek the sun, primarily to tan by a pool for a week; they enjoy the busy activity in the medina as well as the cafes and restaurants of the more modern half of central Marrakech, Gueliz. The ease of travel and proximity is another factor, with many direct, low-cost flights from different cities in France ${ }^{4}$. Regular visitors also build relationships with the individuals they encounter there. Samira has a trusted vendor of leather bags, from whom she buys repeatedly and to whom she brings her friends and previous purchases that need repair. Another woman returns to the same salon in Gueliz on every visit to have her hair colored and straightened, citing the price difference between these services in Europe and in Morocco as a bargain she counts on during her visit. The proximity, low cost, and attraction of the tourist environment may be a significant difference between these Moroccan diasporic experiences and those relayed by Ali and Holden (2006) with regard to Pakistani diasporic visitors.

In these examples, diasporic visitors are much more aligned with tourists. They may have a sense of belonging through their repeated visits, becoming familiar with certain spaces and individuals, but their familiarity emerges almost exclusively in a contexts of consumption. They do not seem to build lasting friendships with local residents, apart from those they encounter through their leisure consumption of hotels, cafes, markets and beauty spas. In some sense, they encounter Marrakech purely as tourists: they experience the dépaysement, or the exoticness of a non-diasporic tourist in their consumption of everything in Marrakech that is unlike their hometowns.

Yet they use their Moroccan identities as well, particularly in interactions with other Moroccans. Samira, for example, when asked where she comes from will always reply that she is saharaouia, from the Sahara. As diasporic tourists, they often speak in Moroccan Arabic, or other local languages (when possible), using their local language skills to bargain for prices. They argue with vendors who give them the 'tourist' price, claiming that they 'know the prices'. They complain about the expensiveness of Marrakech, where prices are known to be much higher than elsewhere in Morocco. Despite these complaints, they continue to return, putting value on the experience they have there above the price differences in comparison to their hometowns. Truthfully, Marrakech offers a much broader variety of entertainment and amusement than other places in Morocco; it is little wonder they choose to visit.

\section{Conclusion: 'tourist' at 'home'}

The experiences recounted here form a sharp contrast to those of Pakistani postmigrant generation individuals in Ali and Holden's study, in that visits are enacted with less of a sense of obligation than with a sense of pleasure. Equally, the trips these diasporic visitors take are not at all limited to family interactions. Instead, they follow much more closely than anticipated a dynamic of touristic experience of Morocco, taking advantage

4. There are many fewer cheap options to visit from Belgium or the Netherlands, however, which may account for the significantly lower numbers of diasporic tourists from these places during data acquisition. 
of the leisure activities that bring most visitors and that, effectively, keep the diaspora coming back.

"Home is implicitly constructed as a purified space of belonging in which the subject is too comfortable to question the limits or borders of her or his experience, indeed, where the subject is so at ease that she or he does not think" (Ahmed 2000: 87). Arguably, this attribution of 'home' applies equally to familial homes as to moments when postmigrant diasporic visitors are touring elsewhere: a main attraction of Morocco is the comfortability of the surroundings, the deep understanding of systems and modes of living in place. Although the activities visitors chose to engage in were much more likely to be motivated by leisure consumption than by the family, they were nevertheless a means of participating in the 'return home' to Morocco. The desire for return, however, usually stops short at the idea of permanently settling there. As one participant said, "Morocco is a great country. But only for holidays"5.

\section{References cited}

Aнmed, Sara, 2000. Strange Encounters: Embodied Others in Post-Coloniality. London: Routledge.

Ali, Nazia and Andrew Holden, 2006. "Post-Colonial Pakistani Mobilities: The Embodiment of the 'Myth of Return' in Tourism”, Mobilities, 1 (2), pp. 217-242.

Anthias, Floya, 1998. “Evaluating 'Diaspora’: Beyond Ethnicity?”, Sociology, 32 (3), pp. 557-580.

Asiedu, Alex, 2005. "Some Benefits of Migrants' Return Visits to Ghana”, Population, Space and Place, 11, pp. $1-11$.

Ateljevic, Irena, and Stephen Doorne, 2003. "Culture, Economy and Tourism Commodities", Tourist Studies, 3 (2), pp. 123-141.

Berriane, Mohamed, 1999. "Tourism, Culture and Development in the Arab Region: Supporting Culture to develop Tourism, Developing Tourism to Support Culture", Paris: Unesco. http://unesdoc.unesco.org/ images/0011/001183/118316eo.pdf

Bertolucci, Bernardo, 1990. The Sheltering Sky, Warner Brothers, 138 min.

Bowles, Paul, 1949. The Sheltering Sky. Hopewell, NJ: Ecco Press.

Brah, Avtar, 1996. Cartographies of Diaspora: Contesting Identities. London: Routledge.

Clayman, Steven E. and Douglas W. Maynard, 1994. "Ethnomethodology and Conversation Analysis", in Paul ten Have and George Psathas (eds), Situated Order: Studies in the Social Organization of Talk and Embodied Activities, pp. 1-30. Washington D.C, Lanham, MD: International Institute for Ethnomethodology and Conversation Analysis, University Press of America.

CoHEn, Robin, 1997. Global Diasporas. London: UCL Press.

Coleman, Simon and Mike Crang (eds), 2002. Tourism: Between Place and Performance. New York: Berghan Books.

Coles, Tim E. and Dallen J. Tiмотнy (eds), 2004. Tourism, Diasporas and Space. London, New York: Routledge.

CRAnG, Phillip, 1997. "Performing the Tourist Product", in Chris Rojek and John Urry (eds), Touring Cultures, pp. 137-154. London, New York: Routledge.

Crouch, David (ed.), 1999. Leisure/Tourism Geographies: Practices and Geographical Knowledge. London: Routledge.

5. «Le Maroc c'est un très beau pays. Mais que pour les vacances ». 
Crul, Maurice and Hans Vermeulen, 2003. "The Future of the Second Generation: the Integration of Migrant Youth in six European Countries”, International Migration Review, 37 (4), pp. 965-986.

Duval, David Timothy,

2003. "When Hosts become Guests: Return Visits and Diasporic Identities in a Commonwealth Eastern Caribbean community", Current Issues in Tourism, 6 (4), pp. 267-308.

2004a. "Conceptualizing Return Visits: A Transnational Perspective", in Tim Edward Coles and Dallen J. Timothy (eds), Tourism, Diasporas and Space, pp. 50-61. London, New York: Routledge.

2004b. "Linking Return Visits and Return Migration Among Commonwealth Eastern Caribbean Migrants in Toronto", Global Networks, 4 (1), pp. 51-67.

FEng, Kathy and Stephen J. PAge, 2000. “An Exploratory Study of the Tourism Migration-Immigration Nexus: Travel experiences of Chinese residents in New Zealand", Current Issues in Tourism, 3 (3), pp. 246-281.

Franklin, Adrian and Mike Crang, 2001. "The Trouble with Tourism and Travel Theory?”, Tourist Studies, $1(1)$, pp. 5-22.

Garfinkel, Harold, 1984 [1967]. Studies in ethnomethodology. Cambridge, UK: Polity Press.

Gaudier, Jean-Pierre and Philippe Hermans (1991). Des Belges marocains : Parler à l'immigré - Parler de l’immigré. Bruxelles : De Boeck.

Gilroy, Paul, 1993. The Black Atlantic: Modernity and Double Consciousness. Cambridge, MA: Harvard University Press.

Hall, C. Michael and Allan M.Williams, (eds), 2002. Tourism and Migration: New Relationships between Production and Consumption. Dordrecht, Boston, London: Kluwer Academic Publishers.

Hochschild, Arlie Russell, 1983. The Managed Heart: Commercialization of Human Feeling. Berkeley: University of California Press.

Hollinshead, Keith, 2004. "Tourism and Third Space Populations: The Restless Motion of Diaspora Peoples", in Tim E. Coles and Dallen J. Timothy (eds), Tourism, Diasporas and Space, pp. 50-61. London, New York: Routledge.

KaTZ, Jack, 1999. How Emotions Work. Chicago, London: University of Chicago Press.

Kirshenblatt-Gimblett, Barbara, 1998. Destination Culture: Tourism, Museums, and Heritage. Berkeley: University of California Press.

Lacoste-Dujardin, Camille, 1992. Yasmina et les autres de Nanterre et d'ailleurs : filles de parents maghrébins en France. Paris : La Découverte.

Lepoutre, David, 1997. Cour de banlieue : codes, rites et langages. Paris : Odile Jacob.

Maccannell, Dean, 1973. "Staged Authenticity: Arrangements of Social Space in Tourist Settings", The American Journal of Sociology, 79 (3), pp. 589-603.

MAssey, Doreen B, 2005. For space. London: Sage.

Mavroudi, Elizabeth, 2007. "Diaspora as Process: (De)Constructing Boundaries", Geography Compass, 1 (4), pp. 467-479.

Meethan, Kevin, 2001. Tourism in Global Society: Place, Culture, Consumption. New York: Palgrave.

Minca, Claudio and Timothy OAKes, (eds), 2006. Travels in Paradox: Remapping Tourism. Lanham: Rowman \& Littlefield Publishers.

NguYen, Thu-Huong, and Brian King. 2004. "The culture of Tourism in the Diaspora: The Case of the Vietnamese Community in Australia", in Tim Coles and Dallen J Timothy (eds), Tourism, Diasporas and Space. London, New York: Routledge, pp. 172-187.

PiCARD, Michel, 1996. Bali. Cultural Tourism and Touristic Culture. Singapore: Archipelago Press. 
Portes, Alejandro and Rubén Rumbaut, 2001. Legacies: The Story of the Immigrant Second Generation. Berkeley, New York: University of California Press, Russell Sage Foundation.

RoJeK, Chris and John Urry, 1997. Touring Cultures. London, New York: Routledge.

SACKs, Harvey, 1998. Lectures on Conversation: Volumes I \& II. Gail Jefferson, ed., Oxford and Cambridge USA: Blackwell.

SCHNAPPER, Dominique, 1999. "From Nation-State to the Transnational World: On the Meaning and Usefulness of Diaspora as a Concept”, Diaspora, 8 (3), pp. 225-255.

ShePHERD, Robert, 2002. "Commodification, Culture and Tourism”, Tourist Studies, 2 (2), pp. 183-201.

Shuval, Judith T, 2000. "Diaspora Migration: Definitional Ambiguities and a Theoretical Paradigm", International Migration, 38 (5), pp. 41-57.

Sмiтн, Valene, (ed.), 1977. Hosts and Guests: The Anthropology of Tourism. Philadelphia: University of Pennsylvania Press.

Stafford, Jean et Charles-Etienne Sarrasin BéLAnger, 1996. Développement et tourisme au Maroc. Montréal : L'Harmattan.

TAÏEB, Eric, 1998. Immigrés : l'effet générations. Paris: Les Éditions de 1'Atelier/Les Éditions Ouvrières.

TÖLÖYAn, Khachig, 1996. "Rethinking Diaspora(s): Stateless Power in the Transnational Moment" Diaspora, 5 (1), pp. 3-37.

Tribalat, Michèle, 1995. Faire France : une grande enquête sur les immigrés et leurs enfants. Paris : Éditions La Découverte.

URrY, John, 1990. The Tourist Gaze: Leisure and Travel in Contemporary Societies. London: Sage.

Van den Berghe, Pierre L., 1994. The Quest for the Other: Ethnic Tourism in San Cristobal, Mexico. Seattle: University of Washington Press.

Werbner, Pnina, 2002. "The Place which is Diaspora: Citizenship, Religion and Gender in the Making of Chaordic Transnationalism", Journal of Ethnic and Migration Studies, 28 (1), pp. 119-133. 